\title{
MI FÁN TEREMNEK A VISEGRÁDI ORSZÁGOK? - AZ EGYÜTTMÜKÖDÉS ORSZÁGAI AZ ALAPVETŐ GAZDASÁGI MUTATÓK TÜKRÉBEN
}

\author{
What about the Visegrad countries? The current economic \\ situation of the countries of cooperation
}

\author{
Máté Anna ${ }^{1}$
}

\begin{abstract}
Absztrakt: A tanulmány bepillantást nyújt a visegrádi országok jelenlegi társadalmi és gazdasági jellemzőibe, abból a meggyőződésből kiiindulva, hogy a hosszútávú, országok közötti együttmúködés alapja a közös gazdasági, társadalmi és külpolitikai érdek, amelynek feltétele az egymáshoz hasonló helyzetből adódó érdekközösség. Napjaink kérdése a visegrádi országok hosszútávú együttmúködésével kapcsolatban többek között az lehet, hogy az együttmúködés továbbra is a közös történelmi szálakon fog nyugodni vagy a jelenlegi társadalmi és gazdasági helyzetük, és az Európai Unión belül elfoglalt pozíciójuk is ösztönzi, majd a továbbiakban az együttes fellépést. A tanulmány arra a következtetésre jut, hogy az érdekközösség pusztán az országok gazdasági helyzete alapján nem áll fenn minden kétséget kizáróan.
\end{abstract}

Kulcsszavak: Visegrádi országok, Európai Unió, Kelet-Közép Európa, Rendszerváltás, gazdasági helyzet

Abstract: The study gives an insight into the current social and economic characteristics of the Visegrád countries, accepting the conviction that longterm cooperation between countries is based on a common economic, social and foreign interest. Today's question -among others- regarding the long-term cooperation of the Visegrad countries whether cooperation will continue to be based on common historical threads or their current social and economic position within the European Union will further encourage the cooperation. The study concludes that a community of interests does

1 A szerzőről: Doktor-jelölt, Eötvös Loránd Tudományegyetem, Társadalomtudományi Kar, Szociológia Doktori Iskola. Elérhetősége: mateanna.phd@gmail.com 
not exist beyond doubt between the countries solely on the basis of the economic situation of them.

Keywords: Visegrad countries, European Union, Central-Eastern Union, Transition countries, economic situation

\section{BEVEZETÉS}

A Visegrádi Együttműködésről számos tanulmány született az elmúlt évtizedben, amelyek annak történeti hagyományait, jelenlegi gazdasági hatásait és külpolitikai lehetőségeit elemzik. Jelen tanulmány nem ezeknek az írásoknak a népes táborához kíván csatlakozni, hanem arra tesz kísérletet, hogy bepillantást nyújtson a visegrádi országok jelenlegi társadalmi és gazdasági jellemzőibe abból a meggyőződésből kiindulva, hogy a hosszútávú, országok közötti együttmúködés alapja a közös gazdasági, társadalmi és külpolitikai érdek, amelynek feltétele az egymáshoz hasonló helyzetből adódó érdekközösség. Az, hogy a történelem során ez a négy ország számos alkalommal találta magát hasonló szituációban, nem vitatható, ugyanakkor napjaink kérdése a visegrádi országok hosszútávú együttmúködésével kapcsolatban többek között az lehet, hogy az együttmúködés továbbra is a közös történelmi szálakon fog nyugodni vagy jelenlegi társadalmi és gazdasági helyzetük, az Európai Unión belül elfoglalt pozíciójuk is ösztönzi majd a továbbiakban az együttes fellépést. Egyszerúbben fogalmazva, következik-e a visegrádi országok jelenlegi gazdasági és társadalmi hasonlóságaikból és különbözőségeikből az érdekegyezés? Ahhoz, hogy ezen a kérdésen alaposabban elgondolkozhassunk, először a visegrádi országok jelenét kell jobban megismernünk.

A visegrádi országok együttműködésének első, diplomácia történeti eseményének a 1335-ös Visegrádi Királytalálkozót is tekinthetjük, ahol nem csak az országok közötti korábbi feszült viszony rendeződött, hanem a Bécs piaci szerepével szembeni közös gazdasági fellépés alapjait is lefektették. Illetve ez a történelmi esemény válik szimbolikus jelentőségűvé a rendszerváltást követően akkor, amikor Csehszlovákia, Lengyelország és Magyarország 1991. február 15-én aláírja a Visegrádi Nyilatkozatot, létrehozva ezzel az akkor még három, később, Csehszlovákia felbomlása után, a négy ország közötti megújított együttműködést. 


\section{A VISEGRÁDI ORSZÁGOK GDP-JE ÉS A KÜLFÖLDI MÜKÖDŐ TŐKE BEÁRAMLÁS}

\subsection{A GDP alakulása az elmúlt évtizedben}

A gazdasági teljesítmény általános mérőszáma a bruttó hazai termék mutató - a továbbiakban az angol kifejezés, Gross Domestic Product (a továbbiakban: GDP). A GDP a Központi Statisztikai Hivatal (a továbbiakban: KSH) meghatározása szerint a GDP az összes megtermelt áru és szolgáltatás értéke csökkentve az előállításukhoz használt áruk és szolgáltatások értékével. A KSH adatai alapján az Európai Unió egy főre jutó GDP-je 27.600 euró volt, de az országok közötti különbségek igen jelentősek. ${ }^{2}$ A legmagasabb egy főre jutó GDP-vel Luxemburg rendelkezik, értéke 81,800 euró, ez olyan kiugró érték, hogy az őt követő Írország GDPjénél is csaknem másfélszer magasabb. ${ }^{3}$ A legalacsonyabb GDP-vel 2017ben Bulgária és Románia rendelkezett, rendre 6300 és 8200 euró/fó értékkel. ${ }^{4}$ A visegrádi országok GDP rangsor tekintetében az uniós országok végén helyezkednek el, egyik ország GDP-je sem közelíti meg az uniós átlagot. Alacsonyabb GDP-vel, 11800 euró/fő értékkel Magyarország és Lengyelország rendelkezik, Szlovákia GDP-je 15000 euró/fö, míg Csehországé 17200 euró/fő volt 2017-ben. Így mind a négy ország az alacsonyabb GDP-vel rendelkező 10 ország közé tartozik. ${ }^{5}$ A válság gazdasági következménye a bruttó hazai termék csökkenése, vagy legalábbis a növekedési ütemének csökkenése: 2008-ig jelentős mértékben emelkedett az országok GDP-je, különösen Szlovákiáé és Csehországé. A vizsgált évtizedben az országok sorrendje egy före jutó GDP tekintetében tulajdonképp állandó: a legmagasabb végig a cseh GDP, amelyet a szlovák, majd a magyar és a lengyel követ. A sorrend 2007 és 2014 között állandó, 2014-et követően a lengyel GDP már megelőzte a magyart. Tendencia tekintetében elmondható, hogy az emelkedő időszakot egy csökkenőstagnáló periódus követte: a gazdasági válság éveiben, 2008 és 2012 között lelassult az országok GDP-jének növekedése és csak 2012 után indul ismét emelkedésnek. Ez alól a trend alól részben kivétel Szlovákia, ahol a GDP növekedés már korábban, 2010-ben megkezdődött, abszolút kivétel viszont

\footnotetext{
2 KÖZPONTI STATISZTIKAI HIVATAL, 2017.

${ }^{3}$ KÖZPONTI STATISZTIKai Hivatal, 2017.

${ }^{4}$ KÖZPONTI STATISZTIKAi Hivatal, 2017.

${ }^{5}$ KÖZPONTI STATISZTIKAi Hivatal, 2017.
} 
Mi fán teremnek a Visegrádi országok? - Az együttműködés országai az alapvető gazdasági mutatók tükrében

Lengyelország GDP növekedés nem lassult le a válság körüli években úgy, mint akár a cseh, akár a magyar GDP növekedése, hanem egyenletes ütemben növekedett tovább. Az 1. számú táblázat a visegrádi országok GDP-jének százalékpontban meghatározott növekedését mutatja.

\begin{tabular}{l|ccccccccccc}
\multicolumn{1}{l}{ ORSZÁG/ÉV } & $\mathbf{2 0 0 7}$ & $\mathbf{2 0 0 8}$ & $\mathbf{2 0 0 9}$ & $\mathbf{2 0 1 0}$ & $\mathbf{2 0 1 1}$ & $\mathbf{2 0 1 2}$ & $\mathbf{2 0 1 3}$ & $\mathbf{2 0 1 4}$ & $\mathbf{2 0 1 5}$ & $\mathbf{2 0 1 6}$ & $\mathbf{2 0 1 7}$ \\
\hline CSEHORSZÁG & 5.6 & 2.7 & -4.8 & 2.3 & 1.8 & -0.8 & -0.5 & 2.7 & 5.3 & 2.5 & 4.4 \\
MAGYARORSZÁG & 0.4 & 0.9 & -6.6 & 0.7 & 1.7 & -1.6 & 2.1 & 4.2 & 3.5 & 2.3 & 4.1 \\
LENGYELORSZÁG & 7.0 & 4.2 & 2.8 & 3.6 & 5.0 & 1.6 & 1.4 & 3.3 & 3.8 & 3.1 & 4.8 \\
SZLOVÁKIA & 0.8 & 5.6 & -5.4 & 5.0 & 2.8 & 1.7 & 1.5 & 2.8 & 4.2 & 3.1 & 3.2
\end{tabular}

1. számú táblázat: A visegrádi országok bruttó hazai termékének növekedése százalékban kifejezve, 2007 és 2017 között. ${ }^{6}$

Ahogy az a táblázatból is kiolvasható, és ahogy már az egy főre jutó bruttó hazai termék növekedése is előre jelezte, Lengyelország GDP növekedése a legstabilabb ütemú. Bár a válság itt is éreztette a hatását azzal, hogy a növekedés a korábbi 5,0 százalékosról 2012-re 1,6 majd 2013-ra 1,4 százalékra esik vissza, a következő években már ismét előbb három, majd négy százalék feletti volt a növekedés mértéke. Különösen figyelemre méltó ez akkor, ha összevetjük a másik három ország trendjével: 2009-ben mind a három visegrádi szomszédja jelentős 4,8 és 6,6 százalék közötti GDP visszaesés tapasztalt, ennek a visszaesésnek második hulláma is jelentkezett 2012-ben és 2013-ban Csehországban és Magyarországon, bár a GDP csökkenésének mértéke ekkor már csak 0,5 és 1,6 százalékpont között változott.

\subsection{A GDP alakulása az elmúlt évtizedben}

A rendszerváltás során a gazdasági környezet megváltozásának egyik kétségkívül markáns eleme a jogszerű magántulajdon és vállalkozás szabadsága volt. Ehhez azonban vállalkozások jogszabályi környezetét, befektetési alapokat kellett megteremteni, a legfontosabb, szimbolikus jelentőséggel is bíró lépés mégis talán az állami tulajdonlás megszüntetése volt. A visegrádi országok különböző privatizációs eljárásokat választottak. Csehországban és részben Szlovákiában a kuponos privatizáció volt a vezetô értékesítési módszer, igaz, később Szlovákia nyílt értékesítéssel is adott el állami

${ }^{6}$ Eurostat adatai alapján saját szerkesztés. 
tulajdont. Lengyelországban ezzel szemben a belsős, managementi vagy munkavállalói kivásárlás volt a leggyakrabban alkalmazott eszköz, amellett megjelent még a kuponos és a piaci értékesítés is. Magyarország volt az egyetlen az országok között, ahol a domináns értékesítési forma a piaci értékesítés volt. Ennek jelentősége a tulajdonosi szerkezet vizsgálatakor érthető meg, míg Magyarországon a tulajdonosok többsége külföldi befektetôk közül került ki, addig a többi országban jellemzően privatizációs alapok jutottak tulajdonhoz, valamint Csehország és Szlovákia esetében bankok, Lengyelországban pedig a „bennfentesek”, azaz a belsős kivásárlás során jutottak tulajdonhoz. ${ }^{7}$ A munkavállalók erős alkupozíciója csak a lengyel privatizációt jellemezte, másik országspecifikus vonás volt a bankrendszer Magyarországéhoz hasonló korai magánosítása, amely gyakorlattal teljesen ellentétes utat választott Csehország, ahol a bankrendszer relatíve késői privatizálásával az állami tulajdonlás tovább maradt meghatározó. A magyar privatizációs eljárás már a korai szakaszában is nagyban épített a külföldi befektetők által az országba áramló pénzre, amely fontos szerepet játszott a makrostabilitás megteremtésében. A magánosítás Lengyelország és Magyarország esetében gyors struktúraváltást és hatékonyság javulást hozott, valamint általa jelentős bevételekhez jutottak az országok, ugyanakkor a folyamat társadalmi támogatottsága közel sem volt olyan jelentős főleg Magyarországon nem, ahol újra és újra korrupció gyanús ügyekre derült fény a magánosítással összefüggésben - mint Szlovákiában vagy kiváltképp Csehországban. Az utóbbi két ország által választott folyamat azonban a másik két országhoz viszonyítva késlekedést eredményezett a struktúraváltásban. Lengyelországban ez elsősorban a mezőgazdaság privatizációjánál látszott. Általánosságban megállapítható a vizsgált országok privatizációs folyamatairól, hogy a korábbiakhoz képest példanélküli mértékben valósult meg, ezért nem volt tudásbázis, amelyre a folyamatot építhették volna, a bizonytalanság, a nehezen átlátható helyzetek, szövevényes jogviszonyok valamint átláthatatlan késlekedő törvényikeretek jellemezték azt.

A privatizációval az országok nyitottá váltak a külföldi közvetlen tőkebefektetésekre (Foreign Direct Investment, a továbbiakban: FDI), amelyeknek jelentôsége különösen a kilencvenes évek közepén nôtt meg. Legnagyobb ütemben Magyarországon, egy év alatt négyszeresére emelkedett a hazánkba érkezó befektetések értéke. A beáramló külföldi tôke

7 TÓTH, ET AL. 2003. 
nagysága olyan mértékű volt, hogy egyes kutatók a magyar privatizációs folyamat legnagyobb nyertesének a külföldi befektetőket tartják ${ }^{8}$, ez azonban az évtized második felében csökkenésnek indult, ellentétben a másik három országba áramló tökével, amely Magyarországénál lassabb ütemben, viszont tovább emelkedett. Szlovákiában ugyanakkor a Meciar kormány leköszönését követően vált csak jellemzővé a külföldi tőke befektetése.

Az Eurostat meghatározása szerint a külföldi múködő tőke beáramlás alatt olyan nemzetközi befektetés kell érteni, amely célja, hogy a befektető gazdaság befektetője tartós érdekeltséghez jusson egy másik gazdaság rezidens vállalkozásában. Az érdekeltség alatt a vállalkozás irányítására gyakorolt hatás is értendő. Az FDI alternatív gazdasági stratégiának tekinthetô, amelyet azok a vállalkozások fogadnak el, amelyek új egység létesítésére fektetnek be, vagy pedig külföldi vállalkozás meglévő eszközeit vásárolják. A közvetlen külföldi befektetéseknek két típusa létezik: termelő eszközök létrehozása külföldiek által, vagy meglévő eszközök vásárlása külföldiek által (például akvizíciók, egyesülések, átvételek révén). Az FDI abban különbözik a portfólióbefektetésektől, hogy azzal a céllal jön létre, hogy ellenőrzést gyakoroljon vagy érdeket képviseljen az érintett vállalkozás vezetésében. A közvetlen befektetés nemcsak magában foglalja a saját tőke kezdeti megszerzését, hanem a külföldi befektetô és a belföldi és kapcsolt vállalkozások közötti későbbi tőketranzakciókat is.

A térségbe áramló közvetlen külföldi tőkebefektetés mértéke meglehetôsen változékony képet mutat. De nem csak változékony, hanem változékonysága aciklikus is, nem függ sem a hazai ország sem a befektető ország gazdasági ingadozásaitól, sôt Magyarország esetében a gazdasági ciklusok sem a teljes FDI-jal, sem annak adósságtípusú, sem befektetés típusú részével nem korrelálnak. ${ }^{10}$ A külföldi tőkebeáramlás csúcspontjának a válságot megelőző két év tekinthető, de ekkor sem érte el az országok többségében a GDP tíz százalékát. Ez alól egyedül Magyarország kivétel, ahol ekkoriban az FDI elérte a GDP közel 50 százalékát. ${ }^{11}$ Ennek következtében a tőkekiáramlás mértéke is Magyarországon volt a legjelentősebb a válságot követően, a GDP közel 16 százaléka. A GDP százalékában forgalmazott részvényekre alapján a visegrádi országok részvénypiacai

\footnotetext{
8 BOTOS, 2015.

${ }^{9}$ Eurostat Foreign Direct InVESTMENT, $2019 .$.

10 TÖKÉS, 2019.

${ }^{11}$ EUROSTAT BALANCE OF PAYMENTS BY COUNTRY, 2019.
} 
kevésbé tekinthetők likvidnek. A gazdaság méretéhez viszonyítva a legaktívabb részvénypiacokkal Csehország és Magyarország rendelkezik itt a kereskedett részvények olykor elérték a GDP egy ötödének megfelelő összeget. Ugyanakkor a magán szektor hitelvolumene megközelíti a GDP csaknem felét, csúcspontján, 2009-ben meg is haladta azt. Ebből is következik a válságot követő évek jelentős GDP visszaesése. A pénzügyi szektor változóinak leíró statisztikáinak összehasonlítása alapján nyilvánvaló, hogy a bankszektor fontosabb a közép-kelet-európai országok számára, mint a tőzsdei piac. ${ }^{12}$

\section{TERMELÉKENYSÉG ÉS A GAZDASÁGI VÁLSÁG HATÁSA A TERMELÉKENYSÉGRE}

Az országok termelékenységét az Eurostat vásárlőerő szabvány mérôszámával mérjük (purchasing power standard, a továbbiakban: PPS), amely egy mesterséges valutaegységként értelmezhető váltószám. Elméletileg egy PPS-en minden országban ugyanazokat az árukat és szolgáltatásokat lehet megvásárolni. A PPS-t úgy hozzák létre, hogy az ország bármely gazdasági aggregátumát nemzeti valutában osztják a megfelelő vásárlóerő-paritásokkal. Vagyis, minél magasabb egy ország PPS értéke, annál nagyobb vásárlóerő potenciállal rendelkezik, vagyis egy közös valutában, amely kiküszöböli az országok és az árszintek közötti különbségeket, így lehetôvé teszi a GDP pontosabb összehasonlítását. A számítás során nem tesznek különbséget a foglalkoztatottak között aszerint, hogy teljes munkaidőben vagy a részmunkaidőben dolgozók-e. A munkaóránkénti munkatermelékenységet a munkaerő-ráfordítás egységenkénti reálkimeneténél számítják ki (a munkaórák teljes számával mérve). A munkaóránként mért munka termelékenységének mérése jobb képet ad a gazdaság termelékenységének alakulásáról, mint az alkalmazottankénti munkatermelékenység, mivel áthidalja a különbségeket a teljes és a részmunkaidős munkavállalás arányai közti eltérésekben országonként és évenként.

12 Vojtovits - KLimaviciene - PiLinkiené, 2019. 
Mi fán teremnek a Visegrádi országok? - Az együttműködés országai az alapvető gazdasági mutatók tükrében

\begin{tabular}{|c|c|c|c|c|c|c|c|c|c|}
\hline ORSZÁG/ÉV & 2009 & 2010 & 2011 & 2012 & 2013 & 2014 & 2015 & 2016 & 2017 \\
\hline CSEHORSZÁG & 79,1 & 77,0 & 77,1 & 76,1 & 76,6 & 79,0 & 79,8 & 80,0 & 81,7 \\
\hline MAGYARORSZÁG & 73,0 & 73,3 & 74,2 & 72,6 & 72,8 & 71,1 & 70,6 & 67,2 & 67,7 \\
\hline LENGYELORSZÁG & 65,1 & 70,0 & 72,2 & 73,8 & 73,7 & 73,4 & 74,1 & 73,8 & 75,3 \\
\hline SZLOVÁKIA & 79,0 & 83,8 & 81,8 & 83,0 & 83,7 & 83,9 & 83,1 & 81,3 & 79,9 \\
\hline
\end{tabular}

2. számú táblázat: A Visegrádi országok termelékenysége, százalékban értelmezve, az Európai Unió 28 országához viszonyítva. (EU28 =100\%). ${ }^{13}$

Csehország és Szlovákia termelékenysége jellemzően magasabb, az Európai Unió 28 tagállamának átlagához jobban közelít, mint Lengyelország vagy Magyarország termelékenysége, ugyanakkor e tekintetben mind a négy ország elmarad az Európai Unió átlagától, és csak az elmaradás nagysága eltérő. Az négy ország termelékenysége nem egyformán reagált a 2008-ban, az Egyesült Államok ingatlan és pénzpiaci eseményei hatására kialakult válságra, amely 2010-re Európába is begyűrűzött és amelynek következtében az országok termelékenysége visszaesett. ${ }^{14} \mathrm{~A}$ visszaesés még a fent leírt módszerrel is mérhető, vagyis akkor is, ha ahhoz az átlaghoz viszonyítunk, amiről feltételezhető, hogy nominál értéken szintén csökkent. A termelékenység visszaesése 2012-es évet követően látszik, a 2010-es évek második felében azonban utolérték, sőt a legtöbb ország meg is haladta a válság előtti termelékenységi szintjét 2017-re. Egyedül Magyarország marad el továbbra is a válság előtti termelékenységtől, esetében a 2010-es évek második felében nem nőtt, hanem ellenkezőleg, tovább csökkent a termelékenység, az Európai Uniós átlag szintjének alig csupán a háromnegyedét érve el. Teljes Uniós összehasonlításban is igen alacsonynak számít ez az arány, Lettországgal holtversenyben kizárólag Románia és Bulgária termelékenységénél magasabb a magyar mutató. Lengyelország termelékenységi adataira érdemes még külön figyelmet fordítani: bár igaz, hogy a válság hatására csökkent az ország termelékenysége, a csökkenés mértéke azonban csak két egymás követôévben történt meg, és mindössze 0,2 százalékot jelentett. Ezután azonban erőteljes növekedési periódus következik, amely eredményeképpen 2009 és 2017 között, az EU28 átlagához viszonyított termelékenység 10,2 százalékpontnyit növekedett, ami az Európai Unió második legnagyobb

${ }^{13}$ Eurostat adatai alapján saját szerkesztés.

${ }^{14}$ BOKROS - PÁL, 2011. 
termelékenység növekedését jelenti - Lengyelországénál jobban csak a román mutató nőtt, 52,6 százalékról, 65,3 százalékra. ${ }^{15}$ A gazdasági válság ellenére is elért növekedést Lehmann a rendszerváltáskor elkezdett és kormányváltásokon át következetesen folyatatott gazdaságpolitika beérésének tekinti. A „lengyel gazdasági csoda” titkát abban látja, hogy a jobboldali kormányok gazdasági reformjait, az azok miatti elégedetlenség okán megválasztott bal-oldali kormányok nem törölték el, legfeljebb intézkedéseikkel enyhíteni igyekeztek a hatásait, így a kormányváltások ellenére is, relatíve folyamatos maradhatott a megkezdett gazdasági reformprogram. ${ }^{16} \mathrm{~A}$ pénzügyi válság befolyásolta a visegrádi országok általános gazdasági teljesítményét: az országok bruttó hazai termékének növekedése átlagosan másfél százalékponttal alacsonyabb a válság utáni időszakban. Bizonyos szempontból a pénzügyi válság a legkiszolgáltatottabb helyzetbe Szlovákiát hozta, annak ellenére, hogy a válság előtt a legnagyobb növekedési ütemben volt, viszont a nemzeti valutáról való áttérés és az Eurózónához történő csatlakozás megszüntette a rugalmas árfolyampolitika lehetőségét, a monetárispolitika, mint a válsághatások mérséklésére irányuló eszköz alkalmazásának lehetőségét. Lengyelországban az erős belső kereslet és a piac viszonylag alacsony nyitottsága miatt kevésbé esett vissza a GDP növekedése, sőt, a máskülönben jellemzően a Visegrádi országok körében legmagasabb munkanélküliségi ráta is a négy ország átlaga alá csökkent, úgy, hogy a válság hatására mind a négy országban emelkedett a munkanélküliség. Különösen Szlovákiában, ahol a munkanélküliség emelkedése majdnem kétszer olyan magas volt, mint a többi országban ${ }^{17}$.

\section{FOGLALKOZTATOTTSÁG ÉS MUNKANÉLKÜLISÉG}

A válság politikai-társadalmi hatásai is a kutatások homlokterébe kerültek a 2010-es évek második felében, több kutatás is foglalkozik a jobboldal megerősödésével, az illiberális vagy neo-konzervatív fordulattal, valamint a populizmus térnyerésével ${ }^{18}$. Az Európában tapasztalható politikai trendeket a visegrádi országokban végzett kutatások is alátámasztják. A

\footnotetext{
15 EUROSTAT LABOUR PRODUCTIVITY PER PERSON EMPLOYED AND HOUR WORKED, 2018.

16 LEHMANN, 2012.

17 PAWETA, 2018.

18 Algan et AL, 2017; Durant, Cohn-Bendit et AL, 2013; Greven, 2016, Segbers, 2018.
} 
kutatások tanúsága szerint, a visegrádi országok politikájában is a jobbra tolódás figyelhető meg: Lengyelország és Magyarország politikájának változását ,illiberális fordulat” jelzővel illetik, míg a cseh és szlovák folyamatokból a „populista elit” előre törését emelik ki a kutatók. ${ }^{19}$ A jelenség egyik kiváltó okaként a kutatások a 2008-ban kezdődő ingatlanpiaci és pénzpiaci válságot jelölik meg. Ennek a válságnak a hatása a Visegrádi országok munkanélküliségi statisztikáiban is megfigyelhetők. A munkanélkülinek az Eurostat definíciója alapján, az a 15 és 74 év közötti személy számít, akinek az elmúlt négy hétben nem volt kereső tevékenysége, a munkanélküliség időtartama pedig ennek megfelelően az az időintervallum, amely az utolsó keresőtevékenységtől számítva eltelt. A legmagasabb munkanélküliségi rátával Szlovákia küzd a visegrádi országok között: már a válság előtt is, a teljes lakosságszámhoz viszonyítva 7,6 százalékos munkanélküliségi rátával rendelkeztek, amely a válság begyűrüzésével 9,1 százalékra emelkedett. ${ }^{20} \mathrm{~A}$ magasabb munkanélküliség időszaka átmenetinek bizonyult, 2013-ban csökkenni kezdett, 2014-2015-re pedig visszaállt a válság előtti mértékre. A magyar és lengyel munkanélküliség alakulása közel hasonló trend szerint alakult: 2009-ben az 5 százalékot közelítő rátáról a 2012-13-ra 6 százalék fölé nőtt a mutató, majd 2013 után határozott csökkenésnek indult, 2018-ra két százalék körüli értékre csökkent. Csehországban a válság körüli években sem nôtt meg jelentősebb mértékben a munkanélküliek százalékos aránya, ám a 2013 után a többi országban tapasztalható csökkenés itt is bekövetkezett. 2018-ban Csehország volt az egyetlen a visegrádi országok közül, ahol a munkanélküliek aránya 2 százalék alatt maradt. Hosszútávú munkanélküliségnek a legalább egy éve tartó keresőtevékenység nélküliség számít az Eurostat meghatározása alapján. A válságot követô öt évben a legalább egy éve munkanélküliek aránya az összes munkanélküliek csoportján belül folyamatosan emelkedett, 2018-ban a munkanélküliségen belül, a hosszú távú munkanélküliség aránya az Európai Unió átlagában az Eurostat adatai szerint 43 százalék. ${ }^{21}$ A visegrádi országokban a hosszútávú munkanélküliség ehhez viszonyítva kedvezőbb, kivéve Szlovákiát, ahol a hosszútávú munkanélküliség kiugróan magas, 61,8 százalék volt. Az adatok arra engednek következtetni, hogy a gazdasági válság hatására nem csak, hogy megemelkedett a munkanélküliek száma, hanem a munkanélküliségben töltött idő is meghosszabbodott, a munkájukat elvesztők nehezebben tudtak

\footnotetext{
19 PAKULSKI (eds) 2018

${ }^{20}$ EUROSTAT UNEMPLOYMENT RATE -ANNUAL DATA, 2019.

${ }^{21}$ EUROSTAT LONG-TERM UNEMPLOYEMENT BY COUNTRY, 2019.
} 
újra munkába állni, mint a válság előtti években, hatványozottan érvényes ez a megállapítás Szlovákiára, ahol hosszútávú munkanélküliség csúcspontján a munkanélküli emberek több, mint kétharmada egy éve, vagy annál régebben nem volt állásban.

\section{IV. ÁLLAMADÓSSÁG ÉS ÁLLAMHÁZTARTÁSI HIÁNY ALAKULÁSA}

Az országok államadósság szempontjából nem azonos kiinduló helyzetből néztek szembe a 2009-es gazdasági válsággal, sőt, már a kilencvenes évek közepén is igen jelentős, és hosszútávon ható államadósságbeli különbségekkel találkozunk. A KSH adatai szerint 1995ben a magyar államadósság a GDP-hez viszonyítva 84 százalékos volt, addig Lengyelországban csak 47,6 százalékos, Szlovákiában 21,7 százalékos, Csehországban pedig kifejezetten alacsony: 13,7 százalékos, vagyis Magyarország eladósodottsága, még a térségen belül őt követő Lengyelországéhoz képest is igen jelentős volt, nem is beszélve akár a szlovák, akár a cseh mértékhez viszonyítva. Az aránybeli különbségek bár mérséklődtek az ezredfordulóra, ám ezt követően ismét növekedni kezdtek. A 2016-os év adatai szerint, elmondható, hogy Csehország ebben a tekintetben határozottan tartja versenyelőnyét a többi országgal szemben, a cseh államadósság ekkor 36,8 százalék, a szlovákok és a lengyelek helyezkednek el egymáshoz legközelebb, rendre 51,8 és 54,1 százalékos mutatókkal, Magyarország államadóssága viszont ismét jóval magasabb, 73,922 százalékos.

Államháztartási hiány tekintetében két csoportra osztható a négy ország: Csehország és Magyarország jellemzően alacsonyabb, Szlovákia és Lengyelország magasabb államháztartási hiánnyal bír.

22 KÖZPONTI STATISZTIKAI HivatAL, 2016. 
Mi fán teremnek a Visegrádi országok? - Az együttműködés országai az alapvető gazdasági mutatók tükrében

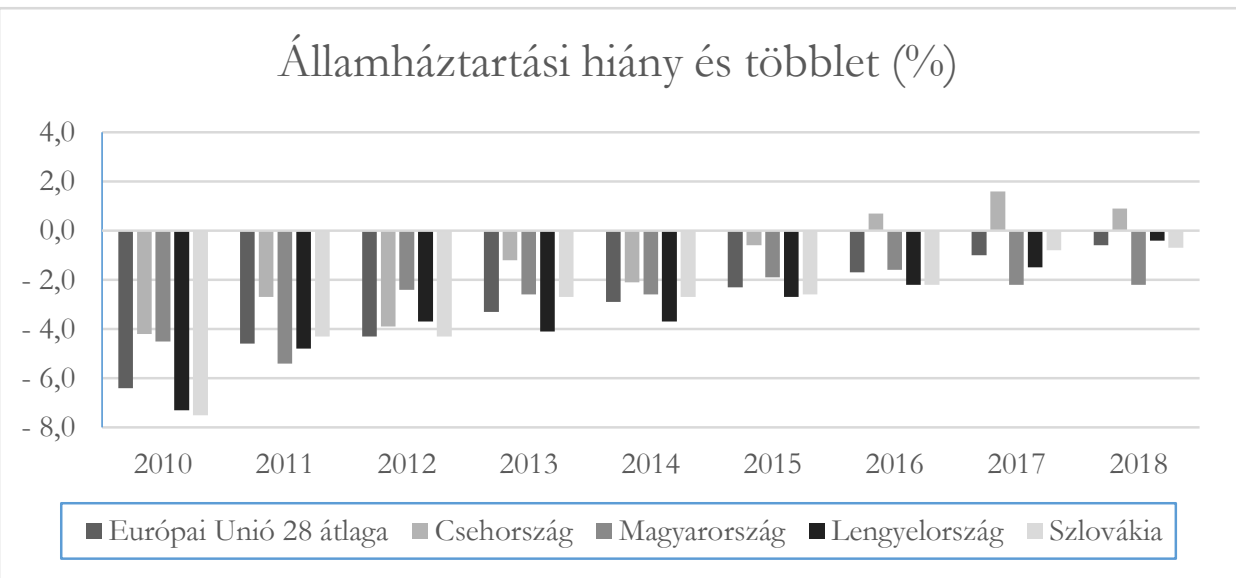

1. számú ábra: Államháztartási hiány és többlet a Visegrádi országokban és az Európai Unió 28 országának átlagában, GDP százalékban megadva, 2010 és 2018 között. ${ }^{23}$

2010-ben az Európai Unió országai átlagosan, a GDP-hez mérten, 6,4 százalékos költségvetési hiánnyal küzdöttek, az Uniós átlagnál alacsonyabb hiánnyal Csehország (4,2 százalék) és Magyarország (4,6 százalék) rendelkezett, az átlagosnál magasabb hiánya volt viszont Lengyelországnak (7,2 százalék) és Szlovákiának (7,5 százalék). ${ }^{24} \mathrm{~A}$ vizsgált időszakban a visegrádi országok mindegyike képes volt az államháztartási hiány csökkentésére: legnagyobb mértékben épp a kevésbé kedvezőbb helyzetből induló Lengyelország és Szlovákia, rendre 6,9 és 6,8 százalékkal csökkentették a hiányukat, 1 százalék alatti szintre. ${ }^{25}$ Csehország az egyetlen a vizsgált országok között, amely államháztartási többlettel rendelkezik, 2016 óta enyhén növekszik is a többlett mértéke 2018-ban a bruttó hazai termék 0,9 százaléka volt. Magyarország a költségvetési hiány csökkentése tekintetében visegrádi szomszédjainál kissé alacsonyabb ütemben teljesít, a vizsgált kilenc éves periódusban 2 százalékkal csökkentette a hiányát, így 2018-ban a

${ }^{23}$ Eurostat adatai alapján saját szerkesztés.

${ }^{24}$ EUROSTAT GENERAL GOVERNMENT DEFICIT (-) AND SURPLUS (+) - ANNUAL DATA, 2018.

${ }^{25}$ EUROSTAT GENERAL GOVERNMENT DEFICIT (-) AND SURPLUS (+) - ANNUAL DATA, 2018 . 
Visegrádi négyek között a legmagasabb, 2,2 százalékos, államháztartási hiánnyal rendelkezik.

\section{JÖVEDELMI SZINTEK ÉS VÁSÁRLÓERÖ PARITÁS}

Az életminőség egyik alkalmas mérőszáma a jövedelmi szint vizsgálata. Az összes háztartás típus átlagában számolt nettó ekvivalens medián jövedelmek alakulását 2009-ben és 2017-ben, az Európai Unió 28 országának átlagával együtt az alábbi táblázat tartalmazza.

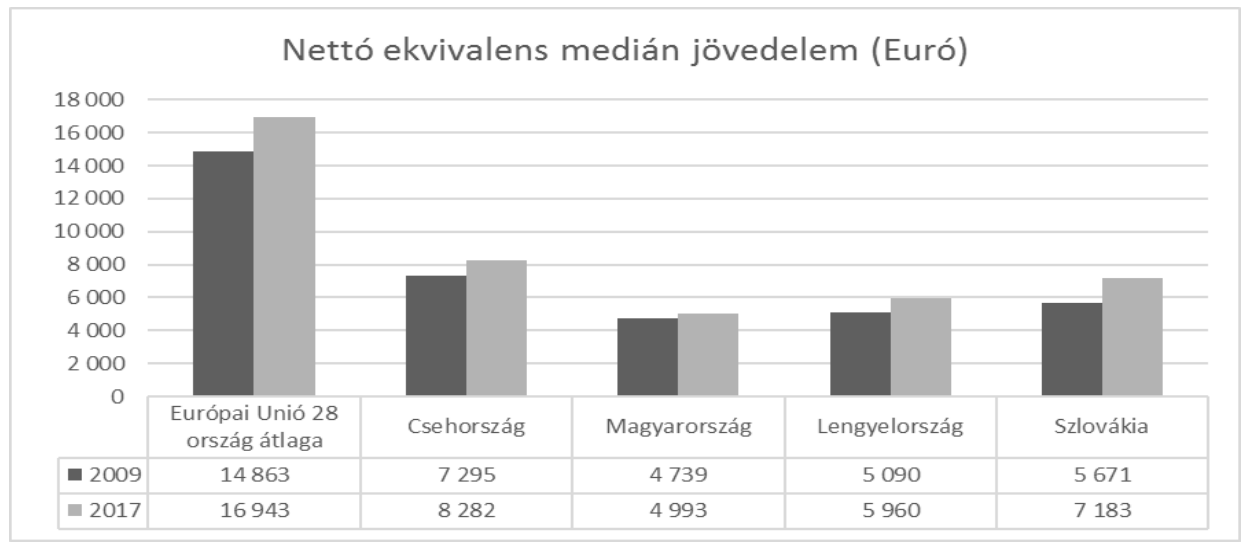

2. számú ábra: Nettó ekvivalens medián jövedelem 2009*-ben és 2017-ben, Euróban megadva. ${ }^{26}$

A 2. számú ábrából két fontos trend olvasható le, egyfelől, hogy a medián ekvivalens jövedelmek nőttek 2009 és 2017 között. A növekedés mértéke az EU 28 országának átlagát tekintve 14,0 százalékos, ennél jelentősebben, mintegy 26,7 százalékkal nőtt a medián jövedelem Szlovákiában, meghaladja az Európai Uniós mértéket a lengyel medián jövedelem növekedése is, amely 17,0 százalékos volt, és megközelíti azt a csehországi is, amely 13,5 százalékpontos. Egyedül a magyar nettó medián jövedelmek növekedése marad el az Uniós átlagtól, a maga 5,4 százalékpontnyi emelkedésével. Az Európai Unió 28 országának átlagos nettó medián jövedelme 2017-ben 16.943 euró volt, ez azt jelenti, hogy a

26 Eurostat adatai alapján saját szerkesztés. Az Európai Unió 28 országának 2009-es rendelkezésre nem állása miatt a 2010-es érték szerepel. 
legmagasabb nettó jövedelemmel rendelkező Csehország is csak az Uniós átlag ötven százalékát közelíti meg. Önmagában a medián jövedelem vizsgálata félrevezető következtetés levonására sarkallhat, fontos a jövedelmi szint vizsgálatát az árszínvonal vizsgálatával kiegészíteni, és megvizsgálni, hogy a fent látott nettó medián jövedelmekhez milyen vásárlóerő társul. A vásárlóerőt az Eurostat vásárlőerő szabvány mérőszámával mérjük, idegenszóval purchasing power standard, rövidítve PPS.

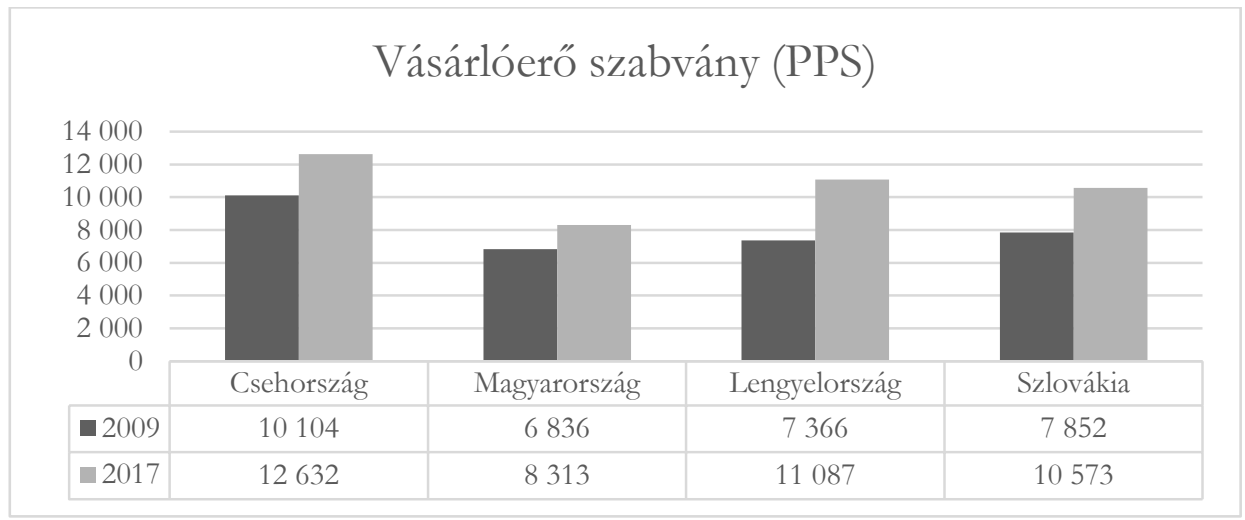

3. számú ábra: Vásárlőerő szabvány 2009-ben és 2017-ben a Visegrádi országokban. ${ }^{27}$

Ami rögtön szembetűnő a diagramot vizsgálva, hogy a magyarországi vásárlőerő elmarad a visegrádi szomszédjaitól. A csehországi vásárlőerő már 2009-ben is jelentősen meghaladta a magyart, ám a Lengyelországhoz és a Szlovákiához mért különbség nem volt ilyen nagy. Ez utóbbi két országnak a vásárló ereje azonban a 2017-re nagymértékben megemelkedett, a lengyel növekedés 50,5 százalékpontnyi, de a Szlovákiáé is meghaladja az egyharmados szintet, 34,7 százalékponttal. A cseh növekedés üteme kisebb mértékű, 25 százalékpontnyi, ám a vizsgált idôszak kezdetén meglévő meghatározó jellegű előnye még 2017-ben is elegendő arra, hogy a másik két országhoz viszonyított relatíve lassabb ütemű növekedése mellett is a legmagasabb vásárlóerővel rendelkezzen továbbra is. Magyarország vásárlóerő növekedése viszont csak 21,6 százalék volt a bemutatott időtartam végpontjai között, így induló hátrányával együtt, ez az adat 2017-re azt

${ }^{27}$ Eurostat adatai alapján saját szerkesztés. 
jelenti, hogy a magyarországi vásárlóerő jelentős mértékben elmarad a többi visegrádi ország vásárló erejétól.

\section{EMBERI FEJLETTSÉGI MUTATÓ}

Az egyes országok fejlettségi szintjének leggyakrabban alkalmazott mérőszáma Human Development Index, magyarul Emberi Fejlettségi Mutató (a továbbiakban: HDI) amelyet azért hozták létre, hogy hangsúlyozza, hogy a fejlődés kritériuma nem lehet kizárólag a gazdasági értelemben vett fejlődés, hanem az emberek és képességeik fejlődése is az országok fejlettségének értékelésébe kell tartoznia. Az index elméleti háttere az Amartya Sen nevével jelzett emberi fejlődési megközelítésen alapul, amely lényege, hogy a fejlődést és fejlettséget abban a kontextusban határozza meg, hogy az emberek lehetősége és képességei mennyire széleskörűek. Lehetőségében áll-e jól tápláltnak, egészségesnek lenni, hozzá fér-e megfelelő oktatáshoz, lakhatáshoz, munkahelyhez, közösségi életben való részvételhez, politikai életben való részvételhez és így tovább. A HDI mutató árnyalhatja az egyéb, elsősorban gazdasági fejlettségimutatókat, mint például a GDP alapú összevetéseket, hiszen azonos egy főre jutó GDP összeg mellett is elképzelhető a HDI indikátoraiban eltérő eredmény, így eltérő emberi fejlettségi szint is. A HDI értéket három dimenzióban összesen négy indikátorral mérik. Az egészségügyi dimenzió indikátora a születéskor várható élettartam, az oktatási dimenziót az oktatásban eltöltött várható és átlagos évek számával mérik, az életszínvonalat pedig az egy főre jutó bruttó nemzeti jövedelem teszi mérhetővé, logaritmikus alapon számolva, így tükrözi az emelkedő jövedelem csökkenő jelentőségét. A három dimenzió átlaga adja a HDI értéket, amelyet az Egyesült Nemzetek Szervezete (a továbbiakban: ENSZ) minden évben, a Föld összes országára megad. ${ }^{28}$ 2018-ban a visegrádi országok a 189 vizsgált ország legfejlettebb negyedébe tartoztak, a rangsorban legmagasabban, 27. helyen Csehország áll, 2017-ben a HDI értéke 0,888. Lengyelország a 33. helyen áll 0,865-ös HDI-vel, Szlovákia a 38. helyen 0,855-ös értékkel, Magyarország tőlük kissé lemaradva a 45. a rangsorban, HDI-je 0,838. Ezzel az értékkel az ENSz besorolása alapján, a „Magasan fejlett országok” csoportjába tartoznak, a „Nagyon magasan fejlett országokhoz” Csehország áll a legközelebb, ide a 0,894-es és magasabb HDI-vel rendelkező országok tartoznak. A világ

28 United Nations DeVelopment Programme, 2017. 
átlagos HDI-je 0,728, míg a Gazdasági Együttmûködési és Fejlesztési Program (Organisation for Economic Co-operation and Development, a továbbiakban: OECD) országainak átlaga $0,895^{29}$. A Föld átlagos fejlettségi szintjénél tehát fejlettebbek a Visegrádi négyek, ám nem tartoznak a világ legfejlettebb országai közé, és az OECD országok átlagától is elmaradnak.

\section{KONKLÚZIÓ}

A fentiek összefoglalásaként levonható az a következtetés, miszerint a visegrádi országok jelenlegi pozíciójában legalább annyi hasonlóság van, mint amennyi különbözőség. Míg a legutóbb bemutatott emberi fejlettségi index szempontjából nem található jelentős eltérés az országok között, addig gazdasági szempontból annál inkább, és bár mind a négy ország hasonló kihívások elé nézett az 1990-es évek derekán, megoldásaik meglehetôsen eltérőek voltak már a kezdetekkor is. Ez az eltérés a választott privatizációs technikákban is megmutatkozott, amelynek jelentősége a vállalat tulajdonlási szerkezet és a külföldi múködő tôke beáramlás alakulásának vizsgálatakor érthető meg. Utóbbi különösen Lengyelországban, de még hangsúlyosabban Magyarországon nyert teret, amely Magyarország esetében olyan jelentős méretűvé nőtt, hogy az a globális gazdasági válságeseményeknek is jobban kiszolgáltatottá tette az országot a másik három visegrádi országhoz képest.

Emellett a társadalommás területitől is alkalmazkodást vár el a tőke igényeihez mérten, kihat az ország foglalkoztatási, oktatási, képzési szerkezetére, de az országon belüli egyenlőtlenségekre is. A visegrádi országok gazdasága mellett célszerű lehet azok társadalmi jellemzőit is megvizsgálni, ugyanis ebben az esteben is találunk egyértelmû hasonlóságok mellett, markáns különbségeket is. Mind a négy ország társadalma a világ fejlett országaihoz hasonlóan elöregedő, csökkenő gyermekszám mellett az időskori függőségiráta növekedése jelent kihívást az országok számára. Ugyanakkor például -többek között- a gazdasági válságra adott válaszul előretörő jobboldali, vagy más kutatók által illiberálisnak vagy neokonzervatívnak nevezett fordulat elsősorban Lengyelországot és Magyarországot érinti.

Míg a szekularizálódás Csehországot, Szlovákiát és Magyarországot egyaránt érinti, a vallásosság, és főként a katolikus egyház fontossága

\footnotetext{
${ }^{29}$ Human DeVElopement IndeX, 2017.
} 
Lengyelországban továbbra is megmarad. A visegrádi négyek jelenének jobb megismeréséhez fontos tanulmányozni napjaink társadalmát, így kerülve közelebb kiinduló kérdésünkhöz, mi elég erős-e a visegrádi országok érdekközössége ahhoz, hogy az együttműködés a jövőben is megmaradhasson, esetleg erősödhessen. Jelenleg, kizárólag a gazdasági helyzet pillanatképének áttekintése után, egyelőre azt mondhatjuk, gazdasági helyzetük és érdekeik nem hasonlítanak minden kétséget kizáróan egymáshoz annyira, hogy közös gazdasági, külpolitikai vagy Európai Uniós fellépés kizárólagos alapja lehetne, ezért célszerű az országok más területeit, külpolitikai érdeket, társadalmi kihívásait is alaposabban megvizsgálni.

\section{FELHASZNÁLT IRODALOM}

Algan, Yann - Guriev, Sergei - Papaioannou, Elias - Passari, Evgenia (2017): The European Trust Crisis and the Rise of Populism, Brookings Papers on Economic Activity. 1-78.o.

Boros Lajos - PÁL Viktor (2011): A gazdasági válság hatásai és a rá adott válaszok különböző földrajzi léptékekben. In: Földrajzi Közlemények. 135. 117-32.o.

BOTOS KATALIN (2015): The transformation and the ownership structure in Hungary. In: KOVÁCS PÉTER - SZÉP KATALIN - KATONA TAMÁs (eds): Challenges for Analysis of the Economy, the Businesses, and Social Progress Elérhető: eco.u-szeged.hu/english/research/scientificpublications/proceedings-of-the-challenges-for-analysis-of-theeconomy/katalin-botos (Letöltve: 2019. október 22.)

Durant, IsABELLE - CoHn-BENDit, DANiEl (2013): The Rise of Populismand Extremist Parties in Europe, The Spinelli Group, European Parliament. Elérhető:

http://www.spinelligroup.eu/sites/spinelli/files/finalpopulismen 0.pdf (Letöltve: 2019. november 9.)

Lehmann Hartmut (2012): The Polish Growth Miracle: Outcome of Persistent Reform Efforts. IZA Policy Paper Series, No. 40. 2-44.o. Greven, Thomas (2016): The Rise of Right-wing Populism in Europe and the United States - A Comparative Perspective. Friedrich Ebert Stiftung. Elérhető:

https://www.fesdc.org/fileadmin/user upload/publications/Rightwing Populism.pdf (Letöltve: 2019. november 9.) 
Mi fán teremnek a Visegrádi országok? - Az együttműködés országai az alapvető gazdasági mutatók tükrében

RÁCZ GYÖRGY (2009): The Congress of Visegrád. In: Visegrád 1335. Bratislava, 2009, 19-29.o.

TŐKÉS LÁSZLÓ (2019) A Magyarországra áramló külföldi működő tőke ciklikus viselkedése. Statisztikai Szemle, 97. évfolyam 4. szám 387-408.o. DOI azonosító: DOI: 10.20311/stat2019.4.hu0387

SEgBers, Klaus - Hegedüs, DÁniel - KuZio, TARAS - Glahn, Cosima (2018): Populism in Europe- an Overview. CGP Working PaperSeries, 09/2018. Berlin: Freie Universität Berlin, Center for Global Politics. Elérhetô: https://nbn-resolving.org/urn:nbn:de:0168-ssoar-60254-9 (Letöltve: 2019. november 9.)

PAKUlSKI, JAN (eds.) (2018). The Visegrad Countries in Crisis. Edited by Jan Pakulski. Collegium Civitas Defilad.

Elérhető: https://depot.ceon.pl/bitstream/handle/123456789/12433/TheVisegrad-Countries-in-Crisis- $\%$ e $\%$ \% 80\%93-ed.-J.-Pakulski2016.pdf? sequence $=1$ \&isAllowed $=y$ (Letöltve: 2019 . november 9.)

PAWETA, BARTOSZ (2018): Impact of the Financial Crisis on business cycle in the Visegrad Group. Entrepre-neurial Business and Economics Review, 6(3), 43-58.o. DOI azonosító: https://doi.org/10.15678/EBER.2018.060303

Vojtovits, SERgei - Klimaviciené, Asta - Pilinkiené, VAjda (2019). The linkages between economic growth and FDI in CEE countries. Ekonomický časopis, 67. 3, 264 - 279.o.

United Nations DeVelopment Programme (2017): Elérhető: http://hdr.undp.org/en/content/human-development-index-hdi (Letöltve: 2019. október 22.)

Adatforrások

EUROSTAT BALANCE OF PAYMENTS BY COUNTRY. Elérhetô: https://appsso.eurostat.ec.europa.eu/nui/show.do?dataset=bop c6 a\&l ang=en (Letöltve: 2019. november 9.)

EUROSTAT FOREIGN DIRECT INVESTMENT. Elérhető: https://ec.europa.eu/eurostat/web/structural-business-statistics/globalvalue-chains/fdi (Letöltve: 2019. október 22.)

EUROSTAT GENERAL GOVERNMENT DEFICIT (-) AND SURPLUS (+) ANNUAL DATA. Elérhetô: https://ec.europa.eu/eurostat/tgm/table.do?tab=table\&plugin=1\&lang uage $=$ en\&pcode $=$ teina200. (Letöltve: 2019. november 9.) 
EUROSTAT LABOUR PRODUCTIVITY PER PERSON EMPLOYED AND HOUR WORKED

Elérhető:https://ec.europa.eu/eurostat/tgm/refreshTableAction.do?tab =table\&plugin $=1 \&$ pcode $=$ tesem160\&language $=$ en. (Letöltve: 2019. november 9.)

EUROSTAT LONG-TERM UNEMPLOYEMENT BY COUNTRY. Elérhető: http://appsso.eurostat.ec.europa.eu/nui/show.do?dataset=une ltu a\&la ng=en. (Letöltve: 2019. november 9.)

EUROSTAT UNEMPLOYMENT RATE - ANNUAL DATA. Elérhető: https://ec.europa.eu/eurostat/en/web/products-datasets/-/TIPSUN20 Letöltve: (2019. november 9.)

HuMAN DEVELOPEMENT INDEX. (2017). Elérhető:

http://hdr.undp.org/en/data.

KÖZPONTI STATISZTIKAI HIVATAL AZ ÁLLAMHÁZTARTÁS ADÓSSÁGA 1995-2016. Elérhető:

https://www.ksh.hu/docs/hun/eurostat tablak/tabl/tsdde410.html (Letöltve: 2019. november 9.)

KÖZPONTI STATISZTIKAI HIVATAL EGY FŐRE JUTÓ GDP (19952017) Elérhető:

https://www.ksh.hu/docs/hun/eurostat tablak/tabl/tsdec100.html (Letöltve: 2019. október 22.) 